\title{
Lack of detectable DNA uptake by transformation of selected recipients in mono-associated rats
}

\author{
Andrea Wilcks*, Bodil BL Jacobsen
}

\begin{abstract}
Background: An important concern revealed in the public discussion of the use of genetically modified (GM) plants for human consumption, is the potential transfer of DNA from these plants to bacteria present in the gastrointestinal tract. Especially, there is a concern that antibiotic resistance genes used for the construction of GM plants end up in pathogenic bacteria, eventually leading to untreatable disease.

Findings: Three different bacterial species (Escherichia coli, Bacillus subtilis, Streptococcus gordonii), all natural inhabitants of the food and intestinal tract environment were used as recipients for uptake of DNA. As source of DNA both plasmid and genomic DNA from GM plants were used in in vitro and in vivo transformation studies. Mono-associated rats, creating a worst-case scenario, did not give rise to any detectable transfer of DNA.

Conclusion: Although we were unable to detect any transformation events in our experiment, it cannot be ruled out that this could happen in the GI tract. However, since several steps are required before expression of plantderived DNA in intestinal bacteria, we believe this is unlikely, and antibiotic resistance development in this environment is more in danger by the massive use of antibiotics than the consumption of GM food harbouring antibiotic resistance genes.
\end{abstract}

\section{Findings}

A major concern in relation to marketing of genetically modified (GM) plants for human consumption is the possible transfer of antibiotic resistance genes used as marker genes in GM plants to the human or animal intestinal microbiota. The uptake of these resistance genes by bacteria present in the gastrointestinal (GI) tract could potentially render pathogens resistant to antimicrobial agents currently used, thereby resulting in untreatable diseases [1].

Transformation is the only known gene transfer mechanism by which bacteria can take up DNA released from plants. Key factors are thus DNA persistence in the GI tract, the availability of competent bacteria, and their state of competence [2]. Several studies indicate that DNA, and especially plant-associated DNA, is able to survive the conditions in the GI tract and be available for uptake by bacteria resident in the gastrointestinal tract [3-8].

\footnotetext{
* Correspondence: anwi@food.dtu.dk

Division of Microbiology and Risk Assessment, National Food Institute, Technical University of Denmark, Mørkhøj Bygade 19, DK-2860 Søborg, Denmark
}

(c) 2010 Wilcks et al; licensee BioMed Central Ltd. This is an Open Access article distributed under the terms of the Creative Commons Attribution License (http://creativecommons.org/licenses/by/2.0), which permits unrestricted use, distribution, and reproduction in any medium, provided the original work is properly cited.
Several of the bacteria found in the GI tract, either carried by the food or innate GI bacteria, have been found to be naturally transformable [9]. But the question is whether these bacteria also possess or develop competence in this environment. In this work we used as recipients the naturally transformable bacteria Bacillus subtilis which is often a contaminant of food, and Escherichia coli and Streptococcus gordonii that are part of the normal gut microbiota. We used mono-associated rats that can be considered as a worst-case model, and as a biological magnifier making it possible to study one bacterial species separately and often in high number. All animal experiments were carried out under the supervision of the Danish National Agency for Protection of Experimental Animals.

\section{Escherichia coli}

In vitro experiments were performed using an overnight culture of DB1317 (Table 1) mixed with plasmid pMR2 $(100 \mu \mathrm{g} / \mathrm{ml})$ in Luria-Bertani (LB) media and incubated at $37^{\circ} \mathrm{C}$. Sampling at 2 and $4 \mathrm{hrs}$ gave rise to transformants on LB media containing chloramphenicol $(25 \mu \mathrm{g} /$ $\mathrm{ml}$ ) at a frequency of up to $10^{-7}$ transformants (TF) per 
Table 1 Bacterial strains and plasmids

\begin{tabular}{|c|c|c|}
\hline $\begin{array}{l}\text { Strains or } \\
\text { plasmids }\end{array}$ & Description & $\begin{array}{l}\text { Reference or } \\
\text { source }\end{array}$ \\
\hline \multicolumn{3}{|l|}{$\begin{array}{l}\text { Bacterial } \\
\text { strains: }\end{array}$} \\
\hline \multicolumn{3}{|l|}{ Escherichia coli } \\
\hline DB1317 & recD1014 (Nuc) & CGSC \\
\hline MS15978 & DB1317 harbouring pMR1, Ap ${ }^{r}$ & This study \\
\hline MS14395 & $\mathrm{DH} 5 \alpha$, recA1, harbouring pMR2, $\mathrm{Cm}^{r}$ & [14], this study \\
\hline \multicolumn{3}{|l|}{ Bacillus subtilis } \\
\hline Strain 168 & $1 \mathrm{~A} 700$ & BGSC \\
\hline \multicolumn{3}{|l|}{$\begin{array}{l}\text { Streptococcus } \\
\text { gordonii }\end{array}$} \\
\hline LTH 5597 & TIGR strain harbouring pMK110, Ery ${ }^{r}$ & [12] \\
\hline \multicolumn{3}{|l|}{ Plasmids: } \\
\hline pMR1 & pBR322 vector, npt/luNcol, Ap ${ }^{r}$ & {$[10]$} \\
\hline pMR2 & $\begin{array}{l}\text { pACYC184 vector, nptll without } \\
\text { promoter, } \mathrm{Cm}^{r}\end{array}$ & [10] \\
\hline pMK110 & $\begin{array}{l}\text { pMG36e vector, npt/l } \Delta \text { Ncol from } \\
\text { pMR1, Ery }\end{array}$ & [15] \\
\hline pAW105 & $\begin{array}{l}\text { pUC19 vector, cat from pC194, } \\
\text { Bacillus thuringiensis replicon, Ap }\end{array}$ & [16] \\
\hline \multicolumn{3}{|l|}{ Plant: } \\
\hline $\begin{array}{l}\text { Solanum } \\
\text { tuberosum cv. } \\
\text { Apriori }\end{array}$ & $\begin{array}{l}\text { Genetically modified potato } \\
\text { containing antisense GBSS (granule } \\
\text { bound starch synthase) and intact } \\
\text { nptll }\end{array}$ & $\begin{array}{l}\text { AVEBE, Foxhole, } \\
\text { The Netherlands }\end{array}$ \\
\hline
\end{tabular}

Abbreviations: Ap ${ }^{r}$ : ampicillin resistance; BGSC: Bacillus Genetic Stock Center; cat: chloramphenicol acetyltransferase gene; CGSC: E. coli Genetic Stock Center; $\mathrm{Cm}^{\mathrm{r}}$ : chloramphenicol resistance; Ery': erythromycin resistance; GBSS: granule bound starch synthase gene;nptll: kanamycin resistance gene.

recipient (data not shown). Plasmid extraction and restriction analysis confirmed that transformants harboured the plasmid pMR2 (data not shown). Cells incubated without addition of plasmid DNA (negative controls) did not give rise to any chloramphenicol resistant colonies. When adding faecal or intestinal samples from germfree rats to the LB medium to a final concentration of $10 \%$, and performing the same experiment as described above, no transformants were detected (detection limit $2.3 \times 10^{-9} \mathrm{TF} / \mathrm{rec}$ ).

Although ex vivo experiments with intestinal and faecal samples could not detect any uptake of DNA, the situation may be different in vivo where specific environmental factors may be present enhancing uptake of DNA by $E$. coli. Therefore an in vivo experiment with $E$. coli strain MS15978 (DB1317 harbouring plasmid pMR1) was performed. Four germfree Sprague-Dawley rats (14-17 weeks old) bred and housed as previously described [6] were dosed p.o. by gavage with $1 \mathrm{ml}$ cell suspension (app. $10^{9} \mathrm{cfu} / \mathrm{ml}$ ) of E. coli strain MS15978 at day 1 of the experiment. One rat served as a control and was not fed with plasmid DNA, while the other three animals received $100 \mu \mathrm{g}$ plasmid pMR2 each working day from day 8 to 17 of the experiment. Dosing the rats with plasmid pMR2 gave us the opportunity to look at uptake (chloramphenicol resistance, $25 \mu \mathrm{g} / \mathrm{ml}$ ) as well as homologous recombination (kanamycin resistance, $500 \mu \mathrm{g} / \mathrm{ml}$ ) by marker-rescue of the deleted $n p t I I$ gene on pMR 1 [10]. The strain colonized the animals to a concentration of up to $10^{11} \mathrm{cfu} / \mathrm{g}$ faeces (Figure 1). However, the plasmid pMR1 was not stably maintained in the strain MS15978 during colonization of the animals. Therefore a selective pressure was put on the plasmid $(1000 \mu \mathrm{g} / \mathrm{rat} /$ day of ampicillin p.o. by gavage) at day 10 to 17 of the experiment. This restored the population of PMR1 containing cells (see Figure 1). At sacrifice at day 17, pMR1 containing E. coli cells were found throughout the intestinal tract at the following app. densities: duodenum: $10^{3}$ $\mathrm{cfu} / \mathrm{g}$; ileum: $10^{6} \mathrm{cfu} / \mathrm{g}$; caecum and colon: $10^{8} \mathrm{cfu} / \mathrm{g}$. Transformants were detected neither in faecal or intestinal samples on Brain Heart Infusion (BHI) media containing either chloramphenicol $(25 \mu \mathrm{g} / \mathrm{ml})$ or kanamycin $(500 \mu \mathrm{g} / \mathrm{ml})$ (detection limit $100 \mathrm{cfu} / \mathrm{g})$.

In this study we observed low-frequency spontaneous transformation of E. coli strain DB1317 growing in LB media without addition of divalent cations or temperature shift, conditions pivotal for high frequency transformation. However, adding faecal or intestinal samples from germfree rats to the LB media let drop the number below the detection limit of $2.3 \times 10^{-9} \mathrm{TF} / \mathrm{rec}$. This could indicate that adding these samples either inhibited uptake of DNA, or that the DNA was degraded in the samples. A recent published paper (Nordgaard et al., 2007) observed the same inhibitory effect of intestinal content from germfree mice on the transformation process of Acinetobacter baylyi. Previous studies incubating plant DNA in GI samples ex vivo showed that the DNA was rapidly degraded in samples from the small intestine, whereas hardly any degradation was observed when incubating the DNA in samples from the lower part of the GI tract [6]. However, DNA persistence was studied using PCR, a sensitive method needing only scarce amounts of DNA for amplification. Studies incubating plasmid DNA in faecal samples from germfree rats showed that by simple gel electrophoresis, the plasmid could not be observed after 10 minutes of incubation, whereas by PCR a strong band could be detected even after $20 \mathrm{~min}$ of incubation (unpublished results). Since the transformation frequency in LB media is already low, the degradation of DNA in the samples is probably lowering the transformation frequency further, so that a possible transfer event is below detection limit. The same may be true for the in vivo studies where no uptake of DNA by $E$. coli could be observed, in concordance with an earlier study showing that although plasmid DNA was detected in the GI tract, the concentration was very low [6]. 


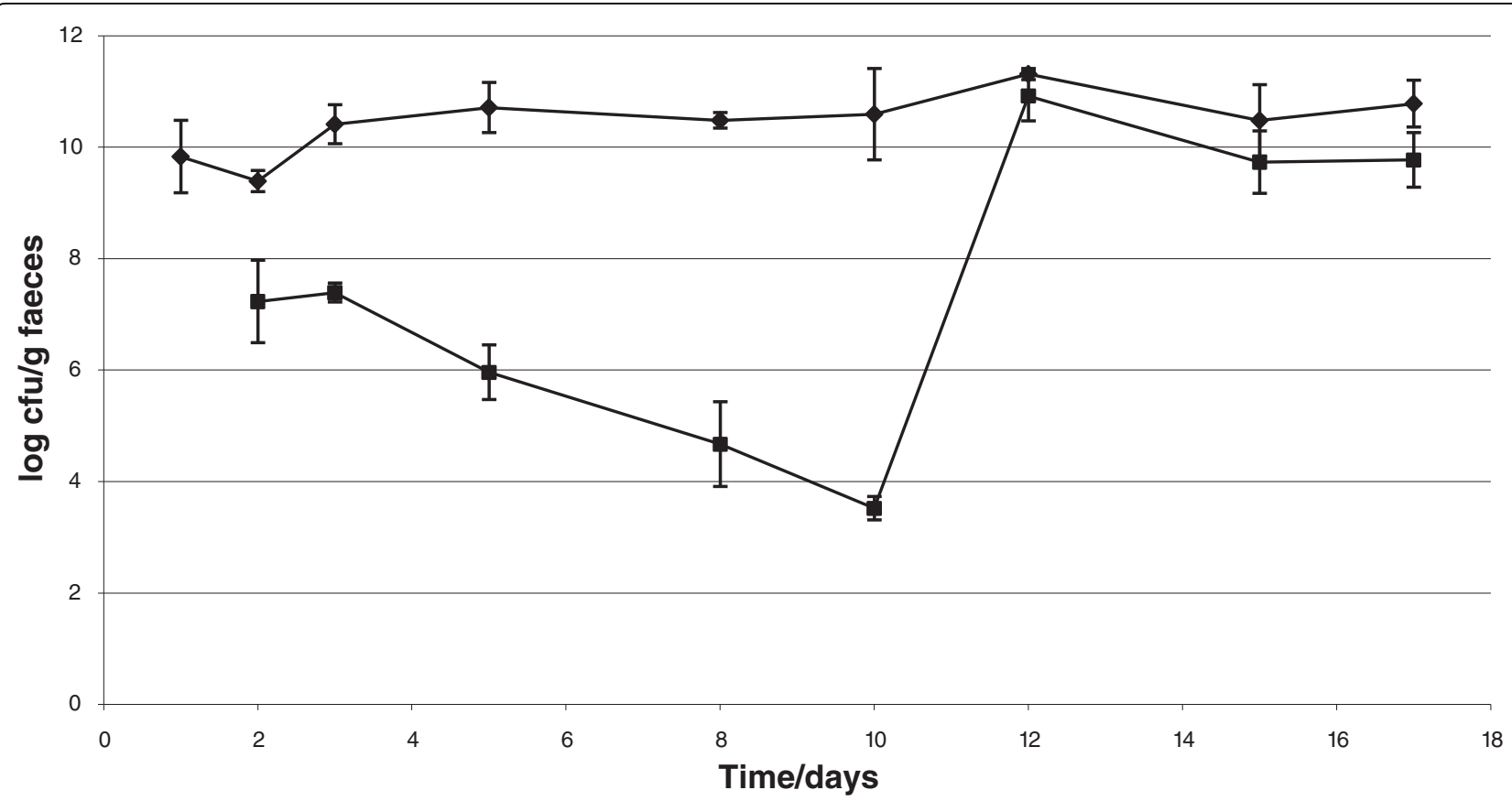

Figure 1 Colonization of four mono-associated rats with E. coli strain MS15978. Faecal samples were plated on both BHI $(\bullet)$ and BHI including ampicillin (-). From day 10 all rats were dosed with $1000 \mu \mathrm{g}$ ampicillin each day to restore the population of pMR1 containing E. coli cells. The detection limit for detection of transformants was $100 \mathrm{cfu} / \mathrm{g}$ faeces. Vertical bars represent standard error of the mean (SEM).

\section{Bacillus subtilis}

Using minimal salt (MS) medium, the plasmid pAW105, and following the in vitro transformation procedure of Spizizen [11] we got a transformation frequency of up to $10^{-6} \mathrm{TF} /$ recipient (Figure 2). PCR with primers detecting pAW105 sequences confirmed that the obtained transformants harboured the plasmid (data not shown). As such the used system for in vitro studies can be regarded as an efficient transformation system. Supplementing the MS medium with $10 \%$ intestinal contents (stomach, ileum, caecum, or colon) from B. subtilis mono-associated rats resulted in transformants from all samples with a frequency of up to $1.1 \times$ $10^{-7} \mathrm{TF} /$ recipients (data not shown). This showed that this concentration of intestinal content allows transformation of B. subtilis to nearly the same extent as in pure MS medium.

One animal experiment was performed with ten germfree rats mono-associated with $B$. subtilis 168 and eight of those fed high amounts of plasmid pAW105. Figure 3 shows that in spite of daily doses of overnight cultures containing app. $10^{9} \mathrm{~B}$. subtilis cells, the bacteria only reached a concentration in faeces ranging from $10^{3}$ to $10^{5} \mathrm{cfu} / \mathrm{g}$. During the experimental period of three weeks, the animals received about $100 \mu \mathrm{g}$ of plasmid DNA each working day, but neither in faecal or intestinal samples transformants on $\mathrm{LB}+\mathrm{Cm}(5 \mu \mathrm{g} / \mathrm{ml})$ were detected (detection limit $10 \mathrm{cfu} / \mathrm{g}$ ).
An explanation of lack of transformants in the rats could be the low number of $B$. subtilis present in the GI tract with app. $10^{3} \mathrm{cfu} / \mathrm{g}$ in ileum, $10^{3} \mathrm{cfu} / \mathrm{g}$ in caecum and $10^{5} \mathrm{cfu} / \mathrm{g}$ in colon. In vitro the highest transformation frequency observed was $10^{-6} \mathrm{TF} /$ recipient. Therefore the likelihood of detection of a transformed B. subtilis within a faecal population of $10^{3}-10^{5} \mathrm{cfu} / \mathrm{g}$ is very low.

\section{Streptococcus gordonii}

Previous published studies have shown that the used strain, LTH 5597, is capable of taking up plasmid DNA and genomic plant DNA under in vitro conditions [12].

The strain LTH 5597 given by p.o gavage to ten germfree rats at day 1 and 4 colonized well (Figure 4 ), but it was noticed that the amount of erythromycin resistant cells was declining during the first week, indicating that plasmid pMK110 was lost from the population. Therefore, from day 8 of the experiment all animals received $100 \mu$ g erythromycin each working day throughout the rest of the experiment. As can be seen from the figure this restored the population of cells containing plasmid pMK110.

At day 7 to 10 of the experiment, eight animals received $1 \mathrm{mg}$ DNA extracted from GM potato; this corresponds to approximately $10^{9}$ nptII genes. Faecal samples were taken and plated onto selective media (BHI containing $1 \mathrm{mg} / \mathrm{ml}$ kanamycin), but no 


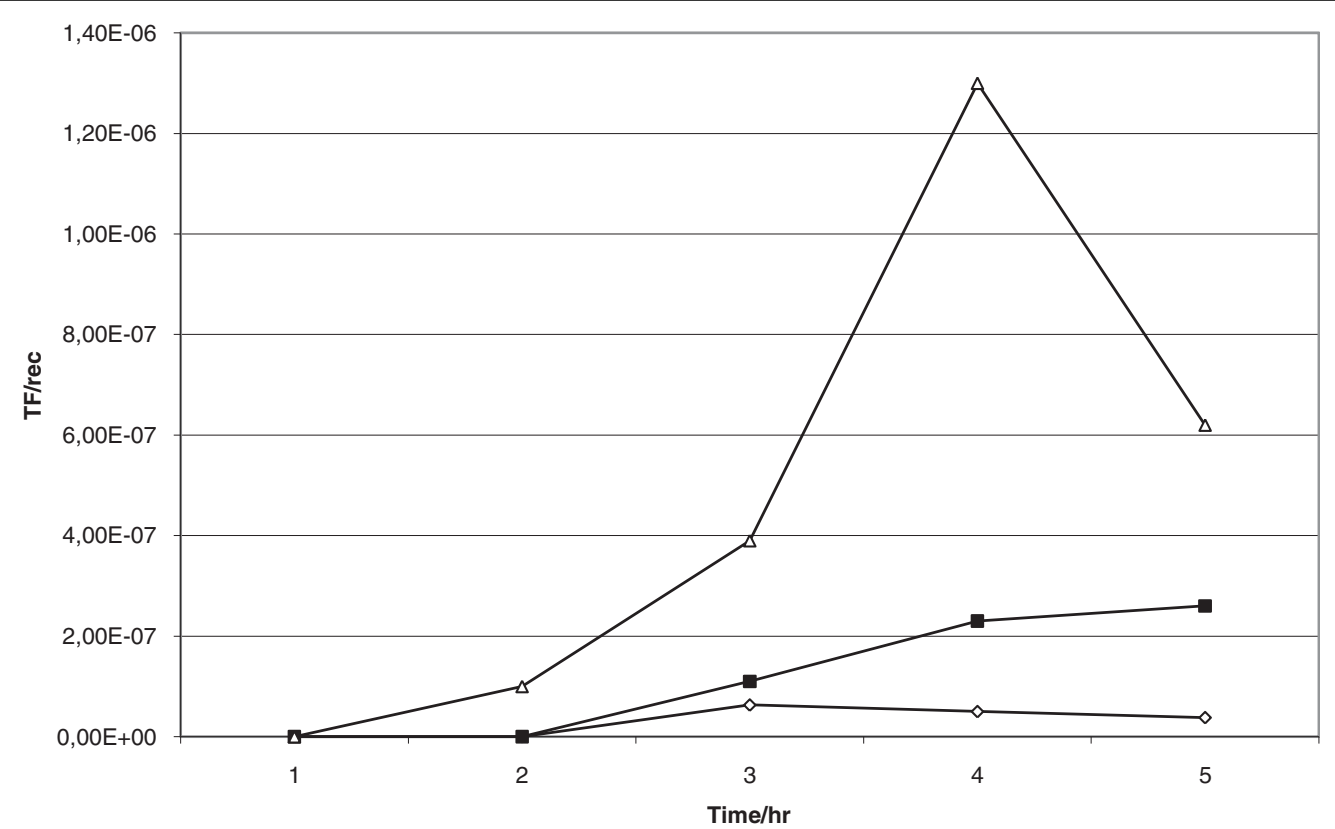

Figure 2 In vitro transformation frequencies (transformants per recipient) of $\boldsymbol{B}$. subtilis $\mathbf{1 6 8}$. An overnight culture was diluted in MS media to $\mathrm{OD}_{450}=0.25$. The culture was grown under aerobic conditions at $37^{\circ} \mathrm{C}$. Every hour, one $\mathrm{ml}$ was taken out and different amounts of plasmid $(0.1 \mu \mathrm{g} / \mathrm{ml}[\Delta], 1 \mu \mathrm{g} / \mathrm{ml}[\bullet]$, and $10 \mu \mathrm{g} / \mathrm{ml}[\bullet]$ were added. The cultures were incubated for further $1 \mathrm{hr}$ before plating on selective media for counting of recipients (LB) and transformants ( $\mathrm{LB}+5 \mu \mathrm{g} / \mathrm{ml}$ chloramphenicol).

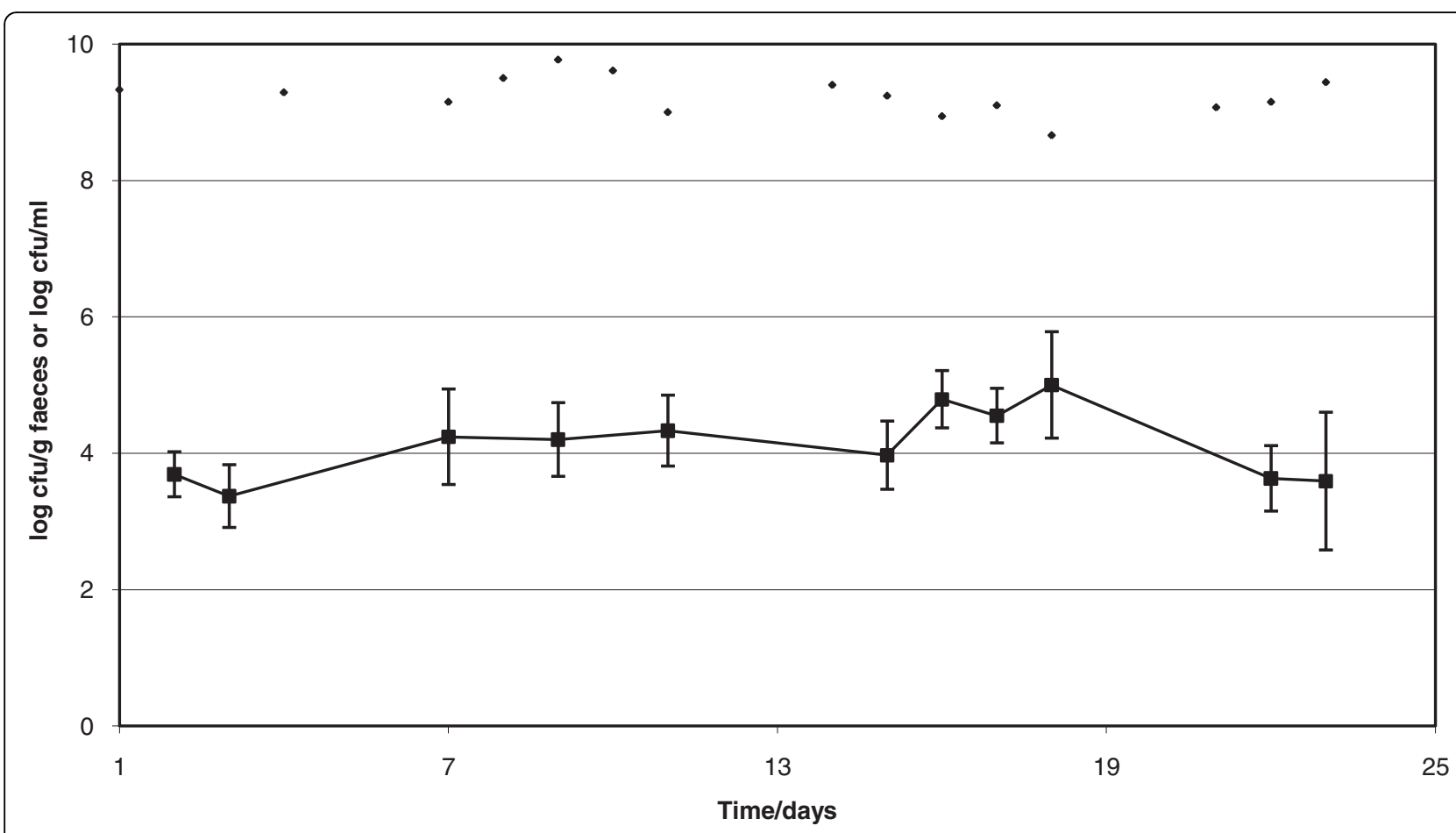

Figure 3 Faecal concentration (cfu/g faeces) of $\boldsymbol{B}$. subtilis recipients ( $\boldsymbol{\nabla}$ ) in eight mono-associated rats. The concentration of the dosage culture (cfu/ml) given during the three weeks is also indicated $(\bullet)$. The detection limit for detecting transformants was $10 \mathrm{cfu} / \mathrm{g}$ faeces. Vertical bars represent SEM. 


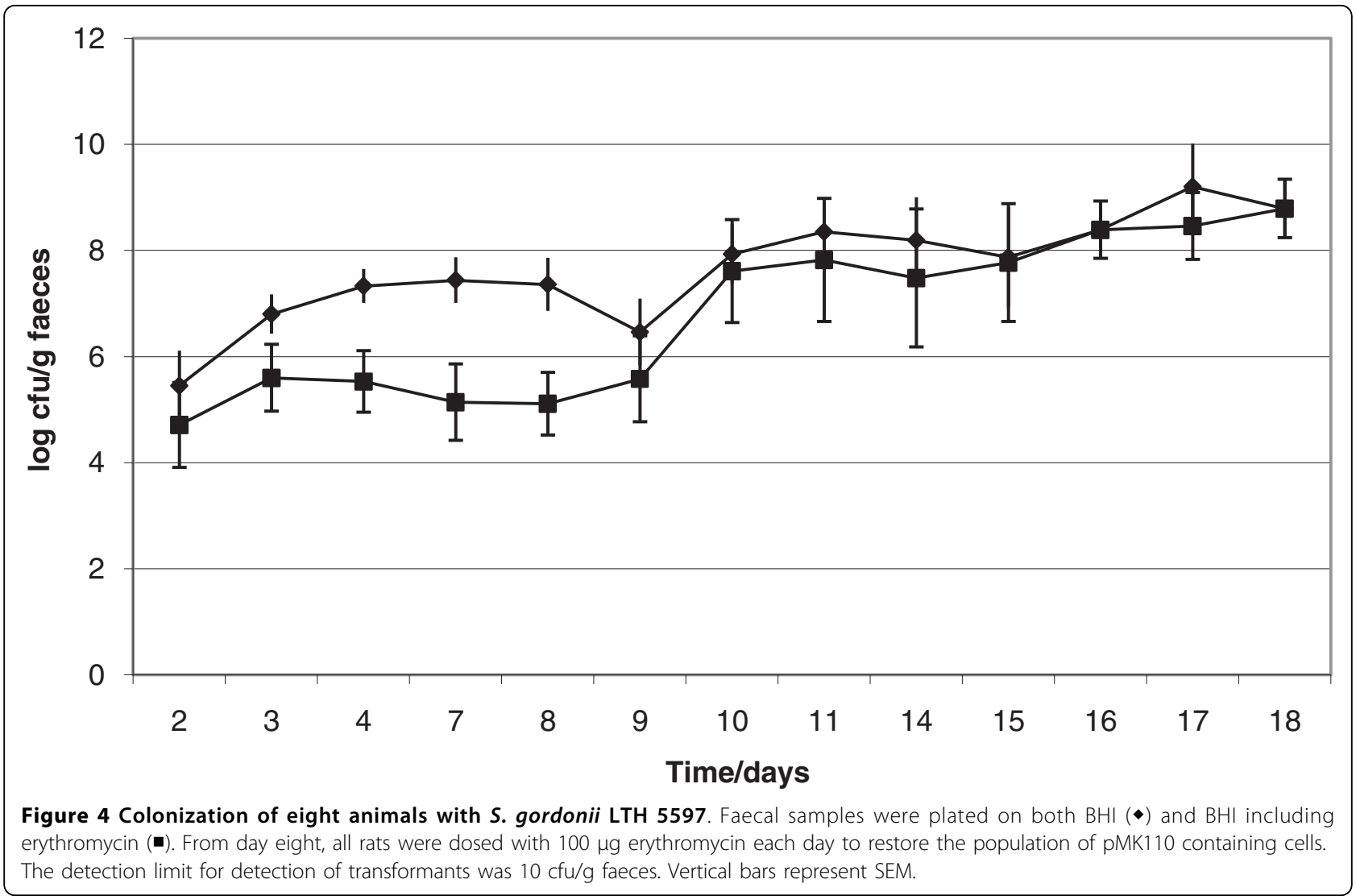

transformants were detected (detection limit $10 \mathrm{cfu} / \mathrm{g}$ faeces). To select for potential transformants, samples were pooled, incubated in Brain Heart Infusion (BHI) media containing $1 \mathrm{mg} / \mathrm{ml}$ kanamycin at $37^{\circ} \mathrm{C}$ overnight, and plated onto selective media containing kanamycin. But again no transformants were detected (detection limit $10 \mathrm{cfu} / \mathrm{ml}$ ).

At day 22 of the experiment, the test animals received an overnight culture of $E$. coli harbouring the plasmid pMR2, which contains a whole copy of nptII but without a promoter. The strain established well in the animals with app. $10^{8} \mathrm{cfu} / \mathrm{g}$ faeces, but again no kanamycin resistant colonies of $S$. gordonii were detected (detection limit $10 \mathrm{cfu} / \mathrm{g}$ faeces). At sacrifice the total number of bacteria in the different sections of the intestine where as following: duodenum: $10^{4} \mathrm{cfu} / \mathrm{g}$; ileum: $10^{6} \mathrm{cfu} / \mathrm{g}$; caecum and colon: $10^{8} \mathrm{cfu} / \mathrm{g}$. And also here no transformants were detected (detection limit $10 \mathrm{cfu} / \mathrm{g}$ intestinal content). This is in agreement with another study with germ free rats mono-associated with $S$. gordonii and fed large amounts of plasmid DNA that also failed to show transformation in vivo [12].

\section{Concluding remarks}

In the present study, the three studied bacterial species were unable to take up free DNA in a germfree animal model. Using germfree mice, another study using Acinetobacter baylyi also failed to show in vivo transformation [13]. However, there are several more transformable bacterial species that are relevant for the intestinal situation [9], so we cannot rule out the possibility of transformation to happen in the GI tract. Nevertheless, many steps are required before a successful transfer of an antibiotic resistance gene from plant to bacteria has occurred. The DNA has to be released from the plant material, the DNA must survive the harsh gastrointestinal environment; competent bacteria must be present and take up the DNA, and finally has the gene to be integrated into the genome in a place where it can be expressed. Therefore the development of antibiotic resistant pathogenic bacteria is much more favoured by the use of antibiotics thereby putting a selective pressure on the intestinal environment, than by the consumption of antibiotic resistance genes present in GM plants.

\section{Acknowledgements}

We want to thank Annette Christensen, Anh Pham and Amir Mujezinovic for their technical assistance, and Anne Ørngren and her co-workers for the handling of the animals. Johann de Vries and Mitra Kharazami are thanked for providing strains and plasmids. The European commission is acknowledged for financial support through the Fifth Framework Programme 1998-2002, project GMOBILITY, proposal no. QLK1-CT-199900527. 


\section{Authors' contributions}

AW participated in the design of the study, carried out the microbial and molecular work, and drafted the manuscript. BJ conceived of the project and participated in the design of the animal studies. Both authors read and approved the final manuscript.

\section{Competing interests}

The authors declare that they have no competing interests.

Received: 9 October 2009 Accepted: 1 March 2010

Published: 1 March 2010

\section{References}

1. Eede GG, Aarts H, Buhk HJ, Corthier G, Flint HJ, Hammes W, Jacobsen B, Midtvedt T, Vossen JJ, Wright AA, et al: The relevance of gene transfer to the safety of food and feed derived from genetically modified (GM) plants. Food Chem Toxicol 2004, 42:1127-1156.

2. Nielsen KM, Bones AM, Smalla K, van Elsas JD: Horizontal gene transfer from transgenic plants to terrestrial bacteria - a rare event? FEMS Microbiol Rev 1998, 22:79-103.

3. Schubbert R, Lettmann C, Doerfler W: Ingested foreign (phage M13) DNA survives transiently in the gastrointestinal tract and enters the bloodstream of mice. Mol Gen Genet 1994, 242:495-504.

4. Schubbert R, Renz D, Schmitz B, Doerfler W: Foreign (M13) DNA ingested by mice reaches peripheral leukocytes, spleen, and liver via the intestinal wall mucosa and can be covalently linked to mouse DNA. Proc Natl Acad Sci 1997, 94:961-966.

5. Schubbert R, Hohlweg U, Renz D, Doerfler W: On the fate of orally ingested foreign DNA in mice: chromosomal association and placental transmission to the fetus. Mol Gen Genet 1998, 259:569-576.

6. Wilcks A, Van Hoek AH, Joosten RG, Jacobsen BB, Aarts HJ: Persistence of DNA studied in different ex vivo and in vivo rat models simulating the human gut situation. Food Chem Toxicol 2004, 42:493-502.

7. Martin-Orue SM, O'Donnell AG, Arino J, Netherwood T, Gilbert HJ, Mathers JC: Degradation of transgenic DNA from genetically modified soya and maize in human intestinal simulations. Br I Nutr 2002, 87:533-542.

8. Duggan PS, Chambers PA, Heritage J, Forbes JM: Survival of free DNA encoding antibiotic resistance from transgenic maize and the transformation activity of DNA in ovine saliva, ovine rumen fluid and silage effluent. FEMS Microbiol Lett 2000, 191:71-77.

9. de Vries J, Wackernagel W: Microbial horizontal gene transfer and the DNA release from transgenic crop plants. Plant and Soil 2004, 266:91-104.

10. de Vries J, Wackernagel W: Detection of nptIl (kanamycin resistance) genes in genomes of transgenic plants by marker-rescue transformation. Mol Gen Genet 1998, 257:606-613.

11. Spizizen J: Transformation of biochemically deficient strains of Bacillus subtilis by deoxyribonucleate. Proc Natl Acad Sci 1958, 47:505-512.

12. Kharazmi M, Sczesny S, Blaut M, Hammes WP, Hertel C: Marker rescue studies of the transfer of recombinant DNA to Streptococcus gordonii in vitro, in foods and gnotobiotic rats. Appl Environ Microbiol 2003, 69:6121-6127.

13. Nordgard L, Nguyen T, Midtvedt T, Benno Y, Traavik T, Nielsen KM: Lack of detectable DNA uptake by bacterial gut isolates grown in vitro and by Acinetobacter baylyi colonizing rodents in vivo. Environ Biosafety Res 2007, 6:149-160.

14. Hanahan D: Studies on transformation of Escherichia coli with plasmids. J Mol Biol 1983, 166:557-580.

15. Kharazmi M, Hammes WP, Hertel C: Construction of a marker rescue system in Bacillus subtilis for detection of horizontal gene transfer in food. Syst Appl Microbiol 2002, 25:471-477.

16. Wilcks A, Smidt L, Okstad OA, Kolsto AB, Mahillon J, Andrup L: Replication mechanism and sequence analysis of the replicon of pAW63, a conjugative plasmid from Bacillus thuringiensis. J Bacteriol 1999, 181:3193-3200.

doi:10.1186/1756-0500-3-49

Cite this article as: Wilcks and Jacobsen: Lack of detectable DNA uptake by transformation of selected recipients in mono-associated rats. BMC Research Notes 2010 3:49.

\section{Submit your next manuscript to BioMed Central and take full advantage of:}

- Convenient online submission

- Thorough peer review

- No space constraints or color figure charges

- Immediate publication on acceptance

- Inclusion in PubMed, CAS, Scopus and Google Scholar

- Research which is freely available for redistribution 